\title{
Population dynamics and life cycle of Hyale barbicornis (Amphipoda, Crustacea) in a blue mussel zone
}

\author{
Takehiko Hiwatari and Takeshi Kajihara
}

\author{
Ocean Research Institute, University of Tokyo, Nakano-ku, Tokyo 164, Japan
}

\begin{abstract}
Population dynamics and life cycle of Hyale barbicornis Hiwatari \& Kajihara from a blue mussel zone were studied in Tokyo Harbor, Japan. Abundance attained a maximum of 3688 individuals $100^{-2} \mathrm{~cm}$ in summer and fell to a minimum of 134 indiv. $100^{-2} \mathrm{~cm}$ in winter. Temperature is an important factor in regulating abundance. Death rate exceeded birth rate during April and May even though birth rate of overwintering females indicated a high value. This was probably due to newborn juveniles being exposed to low temperature. A high birth rate maintained during summer resulted in a peak in abundance. Females reached maturity at a small size $(5 \mathrm{~mm})$ in summer when temperatures were high. On the basis of an in situ growth experiment and size distribution data, the summer population is estimated to live less than 2 mo. Some juveniles born in autumn overwintered as immature females of large size $(7 \mathrm{~mm})$. The overwintering population lived about 8 to 9 mo. Brooding females were present throughout the year, with an abundance peak in spring and a high abundance during summer to early autumn. The life cycle probably consisted of at least 3 overlapping generations. Fecundity varied seasonally.
\end{abstract}

\section{INTRODUCTION}

Hyalid amphipod species occur in dense populations in a wide range of intertidal zones (Barnard, 1974, 1979). Though many hyalid species have been known for a long time, pertinent ecological studies are rare; only density fluctuations of Hyale nilssoni (Moore, 1977) and feeding of Hyale hawaiensis (Joseph, 1972) have been studied.

Taxonomy and distribution of Japanese hyalid amphidpods were studied by Iwasa (1939) and Hiwatari and Kajihara (1981a, b). The hyalid amphipod Hyale barbicornis Hiwatari \& Kajihara is widely distributed in Japan, from Hokkaido to Kyushu. It lives under stones on the shore and on algae in the inner parts of bays and is especially abundant among blue mussels Mytilus edulis galloprovincialis Lamarck, in the intertidal zone (Hiwatari and Kajihara, 1981a).

Preliminary studies revealed that the constant addition of juveniles to the population of Hyale barbicornis throughout much of the year prevent the following of a particular cohort of individuals through their life cycle. Accordingly, the present study deals with birth rates $(\hat{b})$, death rates $(\hat{d})$ and per capita rates of change (r) by the egg-ratio method (Van Dolah et al., 1975); it infers possible mechanisms of density regulation, estimating the life cycle of $H$. barbicornis by including the results of size distributions and the growth experiment.

\section{MATERIALS AND METHODS}

\section{Field study}

Collections were made at low tide twice a month from February 1979 to February 1980 in the blue mussel zone at Harumi pier in Tokyo Harbor $\left(35^{\circ} 38^{\prime} \mathrm{N}\right.$, $139^{\circ} 45^{\prime}$ E), situated in the innermost part of Tokyo Bay. Surface water temperature and salinity were measured after each collection (Fig. 1). The vertical width of the blue mussel zone was about $1.5 \mathrm{~m}$ from the bottom to top $(70 \mathrm{~cm}$ above mean water level). Due to thick accumulations of sediment among the blue mussels in the lower half of the zone, Hyale barbicornis occurred in extremely low density. In contrast, in the upper half of the zone, where little sediment was present, $\mathrm{H}$. barbicornis were abundant. In 2 quadrats $(10 \times 10 \mathrm{~cm})$ 


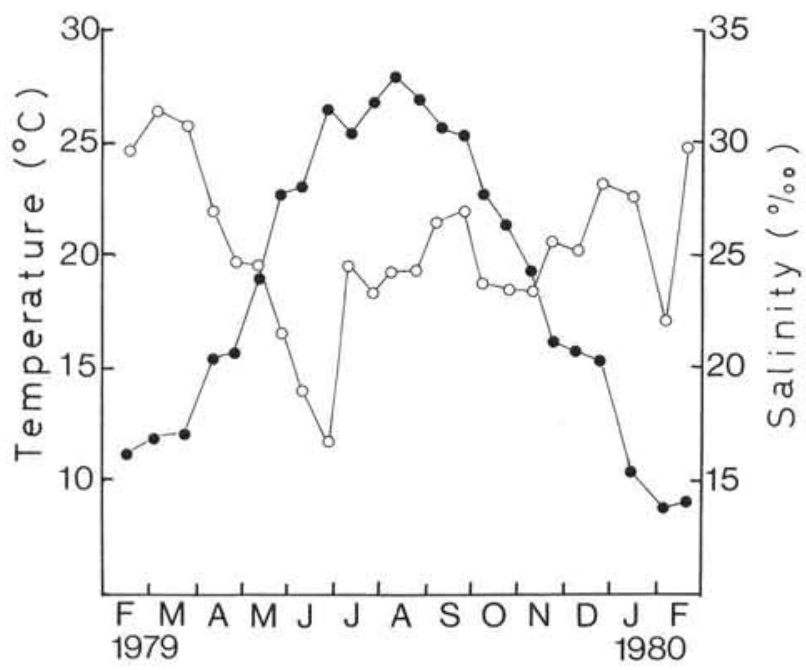

Fig. 1. Seasonal variations in water temperature (solid circles) and salinity (open circles) from 1979 to 1980

blue mussels were sampled together with other members of the community in an area where the blue mussels were evenly distributed in the upper mussel zone. The material sampled was brought back to the laboratory and fixed in $10 \%$ buffered formalin. Animals occurring among the blue mussels were washed into a net with a mesh size of $330 \mu \mathrm{m}$, and then preserved in $5 \%$ buffered formalin. Samples taken in summer and autumn which contained too many animals were divided into $1 / 4$ to $1 / 16$; specimens of $H$. barbicornis were sorted from these subsamples. $H$. barbicornis was the only amphipod species that occurred among the blue mussels.

More than 10000 specimens of Hyale barbicornis were measured. Body length was determined by measuring the dorsal margin from the tip of the head to the end of the telson under a binocular microscope with a camera lucida. Sex was determined from the presence of oostegite in females and the development of the second gnathopod in males. Small individuals for which sex discrimination was difficult were classified as juveniles. Females were separated as follows: immature - oostegites small without setae around their margins; mature - oostegites full size with long setae around their margins. Furthermore, mature females were divided into 'brooding', i.e. those with eggs or juveniles in the brood pouch and 'non-brooding', i. e. those with empty brood pouches. Eggs in brood pouches were counted.

Growth experiments were carried out at Harumi pier from May 5 to July 10, 1978 using experimental sacks. Preliminary experiments showed that hatched juveniles were able to pass through a mesh size of $330 \mu \mathrm{m}$ but unable to pass through $190 \mu \mathrm{m}$ mesh. Two kinds of experimental sacks $(15 \times 15 \mathrm{~cm})$ with mesh sizes of
330 and $190 \mu \mathrm{m}$ were used. At first, only blue mussels (64 to 89 individuals, 24 to $27 \mathrm{~mm}$ in shell length) were packed in a $330 \mu \mathrm{m}$ sack. Sixteen sacks were hung in the upper mussel zone. The mesh size of $330 \mu \mathrm{m}$ allowed immigration of small individuals of Hyale barbicornis from the adjacent mussel zone and artificial cohorts of $H$. barbicornis were established in the sack. After 7 d, further immigration was stopped by wrapping $190 \mu \mathrm{m}$ sacks over the $330 \mu \mathrm{m}$ ones. Growth of cohorts was followed by collecting 2 experimental sacks at a time at intervals of 7 to $19 \mathrm{~d}$. Body lengths of the animals in the experimental sacks were measured and their sex discriminated using the same methods as described above. Surface temperature and salinity ranged between 18.8 and $27.9^{\circ} \mathrm{C}$, and 11.2 and $25.0 \%$ during growth experiments.

\section{Egg developmental time}

The effect of temperature upon the duration of egg development (interval from deposition in the brood pouch to time of hatching) was studied in the laboratory, utilizing the egg ratio method. Amplexus-paired males and females were collected from the field. In the laboratory, individual pairs were kept in glass beakers with about $60 \mathrm{ml}$ of filtered sea water $(25 \%)$ at 10,16 , 20,24 and $28^{\circ} \mathrm{C}$. Tropical aquarium fish food (Tetra$\mathrm{min}$ ) and a green alga, Ulva sp., were offered as food. Water and food were replaced every other day. Females with eggs in the brood pouch were separated from males, and the progress of egg development was observed daily with a binocular microscope.

\section{Egg ratio method}

The egg ratio method (Van Dolah et al., 1975) for accommodating sexually reproducing populations was used in order to analyse population dynamics. The calculations involved in determining the per capita rate of change $(r)$, the estimated birth rate $(\hat{b})$ and death rate $(\hat{\mathrm{d}})$ were simplified so that the female population could be treated separately. Table 1 shows the sex ratio for Hyale barbicornis for the 13 mo period. The values oscillate around 1.0, and the observed variations may be due to differences in the survivorship of males and females. Based on this information, a 1: 1 sex ratio of egg and juveniles was chosen for this species. Egg developmental time at field temperatures were calculated from predictive regression (Fig. 4). The average brood size was calculated as 'total number of eggs $/ 2$ divided by total number of females'. 


\section{RESULTS}

\section{Density trend}

Density trends in the Hyale barbicornis population during 1979 to 1980 are shown in Table 1 . The total population increased from spring to summer and attained a maximum of 3688 individuals $100 \mathrm{~cm}^{-2}$ in August 1979. In autumn the population rapidly decreased and reached 247 indiv. $100 \mathrm{~cm}^{-2}$ in February 1980.

Water temperature ranged from $8.8^{\circ} \mathrm{C}$ in February 1980 to $27.9^{\circ} \mathrm{C}$ in August 1979 (Fig. 1). The seasonal change in population density seems to be closely related to seasonal variations in water temperature. Fluctuation of juvenile numbers coincided with that of the total population from April to December. The number of females and males increased from June and reached a maximum in August; thereafter it decreased. Females were more abundant than males throughout the year except in June, October and November.

\section{Breeding activity}

The relative abundance of immature, brooding and non-brooding females of Hyale barbicornis is shown in Fig. 2. The ratio of brooding females to total females indicates the breeding activity of the population. Brooding females appeared throughout the year. The ratio of brooding females to total females showed a peak in April and maintained a high level from summer to early autumn, in direct opposition to the ratio of immature females to total females. Compared with these 2 ratios, the ratio of non-brooding females to total females was low throughout the year, at most $45 \%$ in October. The peak in the ratio of brooding females in

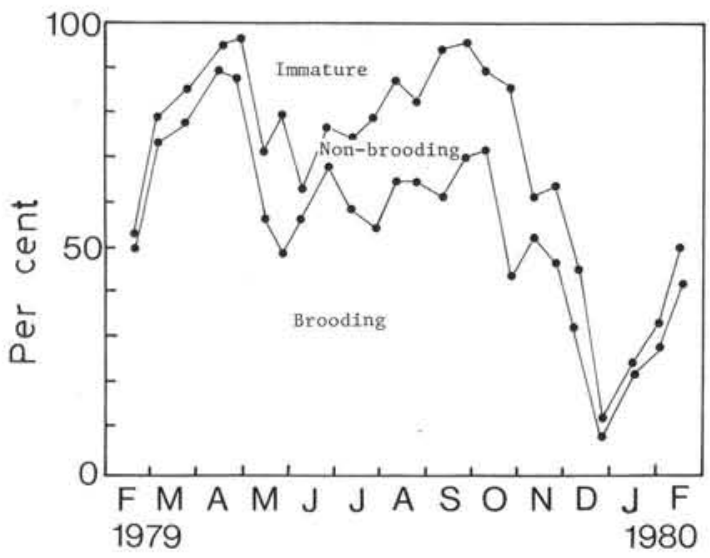

Fig. 2. Hyale barbicornis. Seasonal variations in relative proportion of immature, brooding and non-brooding females of the total female population
April coincides with the beginning of the burst in total population (Table 1). The ratio of brooding females remained above $50 \%$ until late October except in May, declined in winter and was below $10 \%$ in December. In contrast, the ratio of immature females increased in winter, and reached about $90 \%$ in December. Reduction in breeding activity in this season caused a decline in the total population (Table 1).

\section{Size distribution}

Size frequency distributions for males, females (immature and mature) and juveniles are shown in Fig. 3.

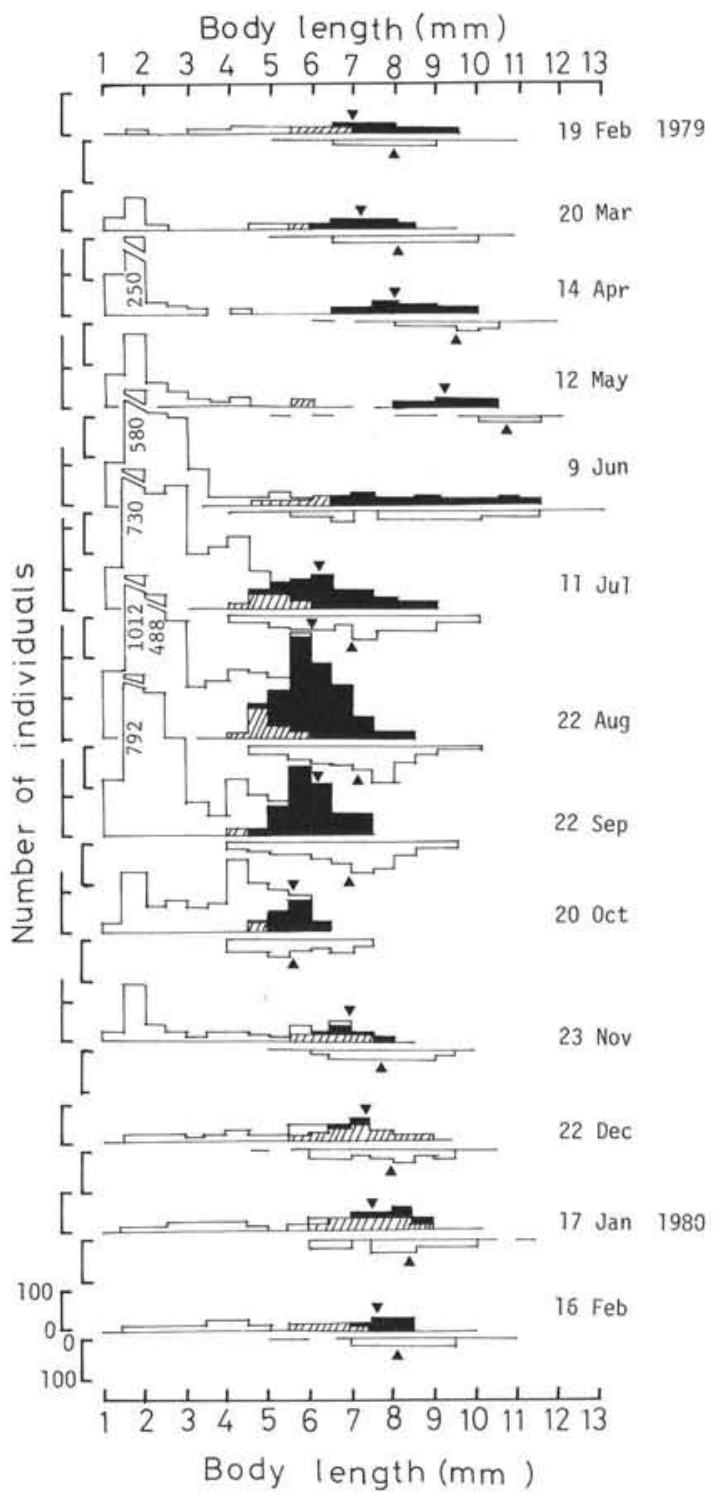

Fig. 3. Hyale barbicornis. Size frequency distribution of males (lower), immature females (cross-hatched, upper), mature females (black, upper) and juveniles (unshaded, upper). Solid triangles: average body length of males and females 
Table 1. Hyale barbicornis. Total population, mean density (indiv, $100 \mathrm{~cm}^{-2}$ ) of juveniles, immature and mature females and males as well as sex ratio for each collection date, 1979 to 1980

\begin{tabular}{|c|c|c|c|c|c|c|}
\hline \multirow{2}{*}{$\begin{array}{l}\text { Collection } \\
\text { date }\end{array}$} & \multirow{2}{*}{$\begin{array}{c}\text { Total } \\
\text { population }\end{array}$} & \multirow[t]{2}{*}{ Juveniles } & \multicolumn{2}{|c|}{ Females } & \multirow[t]{2}{*}{ Males } & \multirow{2}{*}{$\begin{array}{c}\text { Sex ratio } \\
\text { (males/females) }\end{array}$} \\
\hline & & & immatures & matures & & \\
\hline 1979 & & & & & & \\
\hline $19 \mathrm{Feb}$ & 134.0 & 34.5 & 29.0 & 33.0 & 37.5 & 0.6 \\
\hline 2 Mar & 229.5 & 65.0 & 17.5 & 68.5 & 78.5 & 0.9 \\
\hline $20 \mathrm{Mar}$ & 261.5 & 140.0 & 11.0 & 69.5 & 41.0 & 0.5 \\
\hline $14 \mathrm{Apr}$ & 539.0 & 401.5 & 4.5 & 74.0 & 59.0 & 0.8 \\
\hline $28 \mathrm{Apr}$ & 613.5 & 468.0 & 3.5 & 90.5 & 51.5 & 0.5 \\
\hline 12 May & 486.5 & 410.5 & 14.0 & 34.5 & 27.5 & 0.6 \\
\hline 26 May & 794.0 & 670.0 & 18.5 & 71.0 & 34.5 & 0.4 \\
\hline 9 Jun & 1547.5 & 1276.0 & 51.0 & 86.5 & 134.0 & 1.0 \\
\hline 23 Jun & 1552.0 & 1211.5 & 36.5 & 120.5 & 183.5 & 1.2 \\
\hline $11 \mathrm{Jul}$ & 2646.5 & 1951.5 & 102.5 & 296.0 & 296.5 & 0.7 \\
\hline $26 \mathrm{Jul}$ & 1948.5 & 1248.0 & 88.0 & 340.5 & 272.0 & 0.6 \\
\hline $10 \mathrm{Aug}$ & 2796.5 & 1652.0 & 96.5 & 668.0 & 380.0 & 0.5 \\
\hline $22 \mathrm{Aug}$ & 3688.0 & 2468.0 & 147.5 & 692.0 & 380.5 & 0.5 \\
\hline 8 Sep & 2652.0 & 1643.5 & 36.0 & 604.5 & 368.0 & 0.6 \\
\hline 22 Sep & 2700.5 & 1863.5 & 20.0 & 472.5 & 344.5 & 0.7 \\
\hline $5 \mathrm{Oct}$ & 2408.5 & 1816.0 & 27.5 & 224.5 & 340.5 & 1.4 \\
\hline 20 Oct & 1148.0 & 800.0 & 23.5 & 144.0 & 180.5 & 1.1 \\
\hline 7 Nov & 862.5 & 573.5 & 48.0 & 76.5 & 164.5 & 1.3 \\
\hline $23 \mathrm{Nov}$ & 604.0 & 362.0 & 32.0 & 58.0 & 152.0 & 1.7 \\
\hline $6 \mathrm{Dec}$ & 786.5 & 413.5 & 110.5 & 92.0 & 170.5 & 0.8 \\
\hline $22 \mathrm{Dec}$ & 538.5 & 257.5 & 136.5 & 16.5 & 128.0 & 0.8 \\
\hline \multicolumn{7}{|l|}{1980} \\
\hline $17 \mathrm{Jan}$ & 428.5 & 126.0 & 162.0 & 52.5 & 88.0 & 0.4 \\
\hline $1 \mathrm{Feb}$ & 332.5 & 77.5 & 110.0 & 56.5 & 88.5 & 0.5 \\
\hline $16 \mathrm{Feb}$ & 247.0 & 112.5 & 43.5 & 44.0 & 47.0 & 0.5 \\
\hline
\end{tabular}

Small juveniles (1.1 to $2.0 \mathrm{~mm}$ ) constituted the bulk of the population throughout the year except from December to February; their abundance reached a maximum in August. The overwintering group (average body length: female, $7.0 \mathrm{~mm}$; male, $8.0 \mathrm{~mm}$ ) in February 1979 started to grow again and matured following the increase in temperature in spring. Their body length attained $9.2 \mathrm{~mm}$ for females and $10.7 \mathrm{~mm}$ for males in May, and they disappeared in July. Juveniles produced by overwintering females in spring grew and matured at a body length of $6.5 \mathrm{~mm}$ in June. This indicates that 2 groups of mature females were present in June: a group of larger overwintering females and a group of smaller females born in spring. Juveniles produced by both groups of mature females in early summer grew and matured at a small size $(5.0 \mathrm{~mm})$; they accounted for the population burst in summer. Juveniles produced in autumn by females that matured in summer grew slowly at the low temperatures, and some of them overwintered as immature females of large size $(7.0 \mathrm{~mm})$. This accounts for the abundance peak of immature females in winter (Fig. 2). As abundant recruitment of juveniles from spring to autumn prohibited following a particular cohort of individuals, it is difficult to determine the life span of individuals produced in spring and summer. However, as recruitment of juveniles to the population from late autumn to winter is very low, the life span of overwintering individuals, born in early autumn and surviving until June, is estimated to be about 8 to $9 \mathrm{mo}$.

\section{Egg ratio analysis}

Fig. 4 presents the results of the egg developmental study. Duration of egg development (D) was inversely and exponentially related to temperature $(\mathrm{T}): \mathrm{D}=$ $34.16 \mathrm{e}^{-0.058 \mathrm{~T}},(\mathrm{r}=0.93)$.

Birth rate rose above 0 throughout the year (Fig. 5). The activity in $\hat{b}$ showed the spring peak $(>0.2$ indiv. $\left.{ }^{-1} \mathrm{~d}^{-1}\right)$, and thereafter oscillated around 0.1 indiv. ${ }^{-1} \mathrm{~d}^{-1}$ till early autumn. The spring peak is due to the reproductive output of the overwintering females, while a high level of $\hat{b}$ during summer to early autumn represents the reproduction from the summer population. In spring, death rate was slightly higher than $\hat{b}$, despite an apparent reproductive increase; hence amphipod densities remained low. Death rate also rose above $\hat{\mathrm{b}}$ during autumn and winter because reproduction rapidly decreased at this time and so did the amphipod densities. 


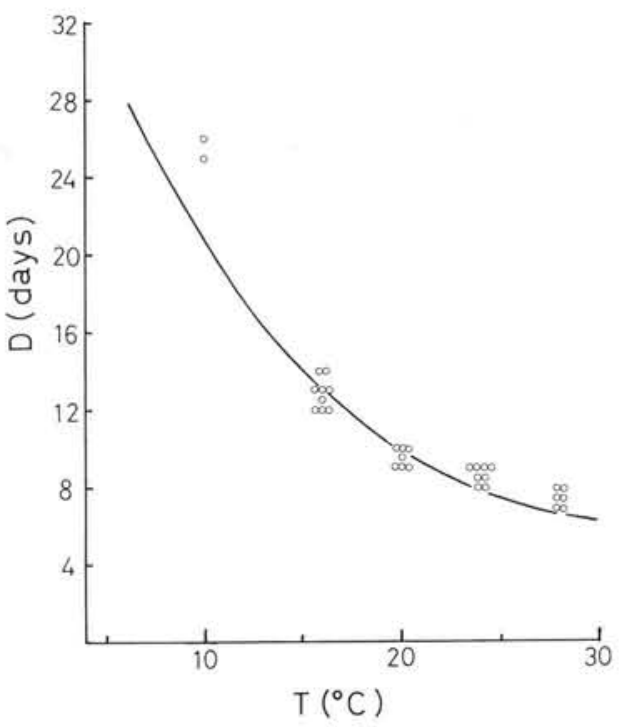

Fig. 4. Hyale barbicornis. Duration of egg development (D) at various temperatures $(\mathrm{T})$

\section{Fecundity}

Seasonal changes in body length of brooding females and in egg number per brood are shown in Fig. 6. Both body length and egg number per brood increased in spring and reached maxima of $9.1 \mathrm{~mm}$ and 23 eggs respectively in May. This indicates that large overwintering females produce many eggs per brood. From summer to autumn both body length and egg number per brood declined, reaching a minimum of $5.9 \mathrm{~mm}$ in October and of 4 eggs in November, respectively. Body length of brooding females increased in winter; they were then larger than in summer and autumn. On the other hand, egg number per brood in winter was similar to that in summer and autumn.

\section{Growth}

The growth of Hyale barbicornis in experimental sacks during $59 \mathrm{~d}$ is shown in Fig. 7. At the start of the experiment average body length of the cohort was $2.1 \mathrm{~mm}$. On Day 22 immature females and males were present, and on Day 29 both brooding and non-brooding females and newborn juveniles (2.1 to $3.5 \mathrm{~mm}$ ) appeared in the experimental sacks. At this time, both males and females of the cohort were $7.0 \mathrm{~mm}$ in average body length. On Day 40 the average body lengths of males and females were $8.6 \mathrm{~mm}$ and $7.9 \mathrm{~mm}$ respectively, and on Day 59 the number of individuals in the experimental sack rapidly declined; only a few juveniles, mature females and males were found. It is

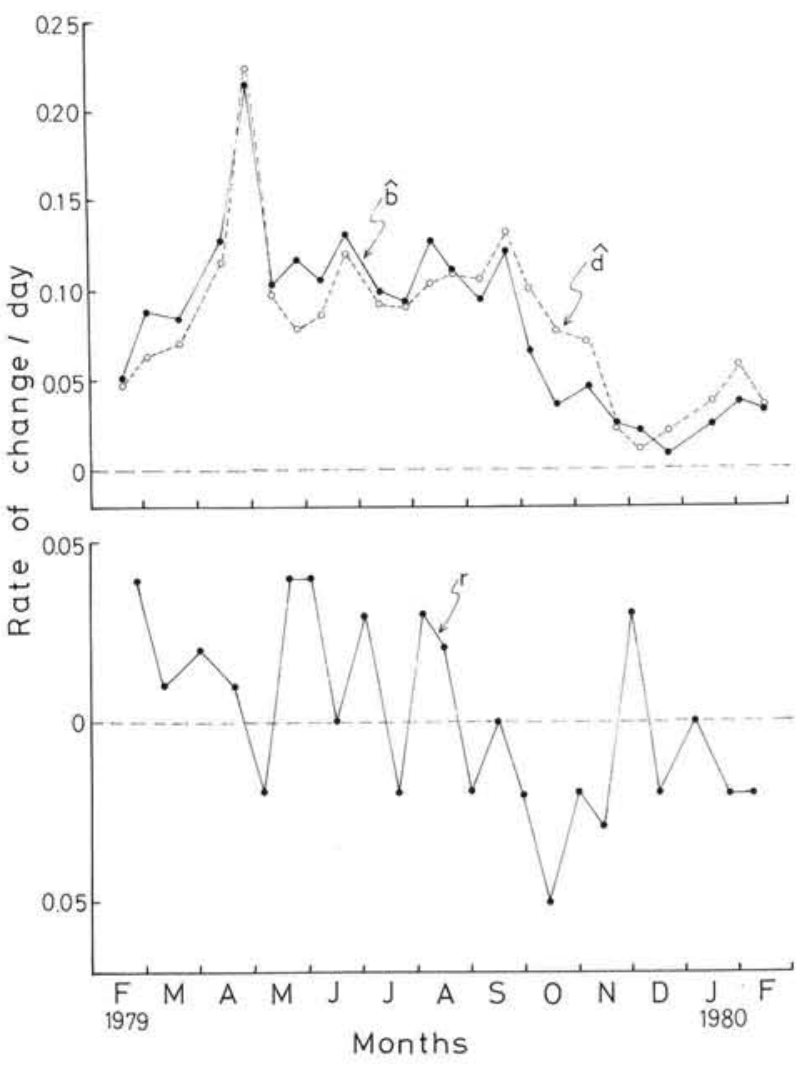

Fig. 5. Hyale barbicornis. Seasonal variation in estimated birth rate $(\hat{b})$, death rate $(\hat{d})$ and per capita rate of change $(r)$. Tokyo Harbor, 1979 to 1980

not clear whether the males and females with body lengths in the range of 7 to $10 \mathrm{~mm}$ on Day 59 were derived from the initial cohort or from the second cohort of small juveniles (2.1 to $3.5 \mathrm{~mm}$ ) which appeared in the experimental sack on Day 29, because

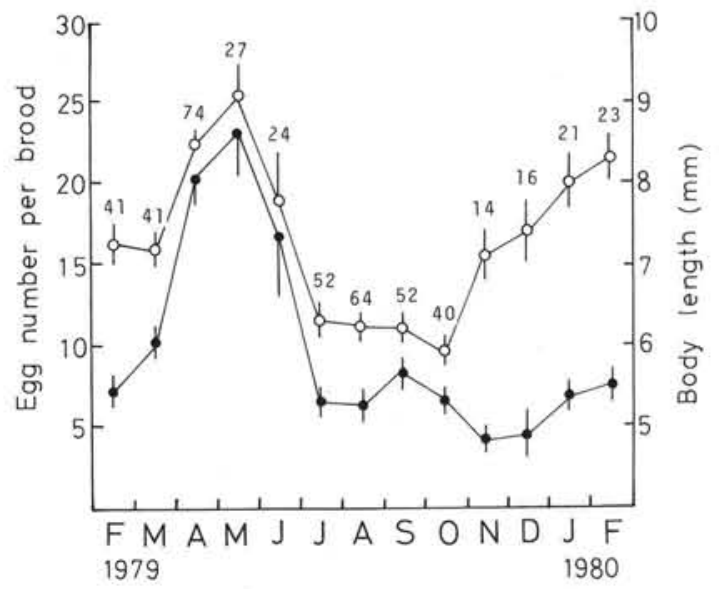

Fig. 6. Hyale barbicornis. Seasonal variations in average body length (open circles) and average egg number per brood (solid circles) of brooding females. Vertical bars: double standard deviation; numbers on curves: numbers of amphipods examined 


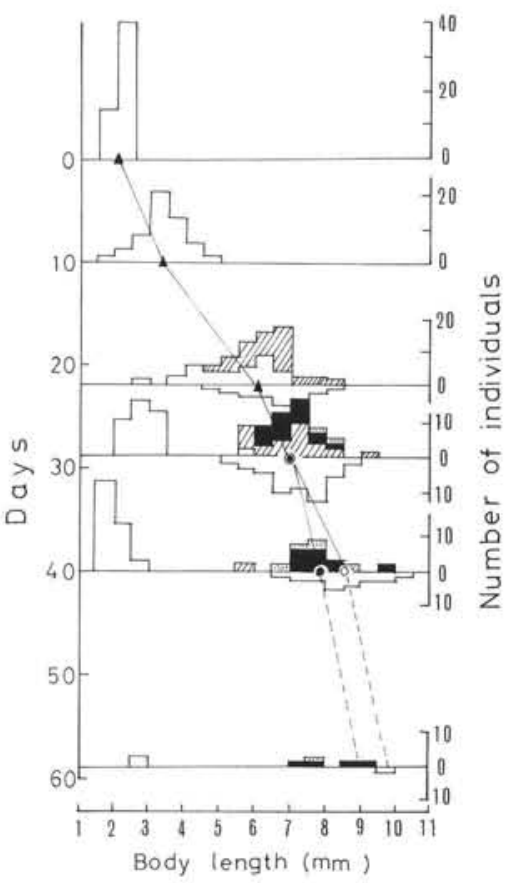

Fig. 7. Hayle barbicornis. Size frequency distributions and growth of a cohort established in experimental sacks from 12 May to 10 July. Males: lower histograms; immature (crosshatched), brooding (black), non-brooding (dotted) females and juveniles (unshaded): upper histograms. Solid triangles: average body length of all individuals in experimental sacks; solid and open circles: average body length of females and males, respectively

there was a long interval between Day 40 and Day 59 when observations were not made. At any rate, the first cohort survived at least more than $40 \mathrm{~d}$. The growth rate for the $29 \mathrm{~d}$ in which the first cohort reached maturity was calculated to be $0.17 \mathrm{~mm} \mathrm{~d}^{-1}$.

As high temperatures continued for an unusually long period during summer 1978, most of the blue mussels attached to the pier died and the mussel zone broke up in August. The decrease in the number of Hyale barbicornis on Day 59 appears to be the result of a change for the worse in conditions in the experimental sacks because of the high temperatures and the clogging of mesh due to attached diatoms. Though juveniles born in the experimental sack on Day 29 were expected to grow into large individuals by Day 40 , in fact only 2 individuals $(5.5$ and $6.0 \mathrm{~mm}$ ) were found on Day 40. The decrease in the number of juveniles probably also indicates a deterioration in conditions in the experimental sacks.

Applying the growth data to the size distribution from May to August in Fig. 3, some of the juveniles born in May are estimated to have become small mature females by June. Assuming that females (8.5 to $9.5 \mathrm{~mm}$ ) on Day 59 survived from the initial cohort, females ( 8.5 to $9.5 \mathrm{~mm}$ ) in July (Fig. 3) probably sur- vived from juveniles born in May. The maximum size $(8.5 \mathrm{~mm})$ of females in August was smaller than that of females in July (Fig. 3). The large females (8.6 to $9.0 \mathrm{~mm}$ ) in July probably died by August. This fact indicates that most of the juveniles born in May were no longer alive in August. For this reason, juveniles born in May are thought to live for $2 \mathrm{mo}$.

\section{DISCUSSION}

Fluctuation of temperature is an important factor influencing the abundance of Hyale barbicornis. Females reached maturity at a small size at high temperatures in summer. The same finding was reported, for example, in Hyalella azteca (Cooper, 1965), Neohaustorius schmitzi (Dexter, 1971), Corophium insidiosum (Sheader, 1978) and Gammarus palustris (Van Dolah, 1978). H. barbicornis females produce several broods during their lifetime and the interval between broods decreases with increasing temperature (Hiwatari, unpubl.). For these reasons the recruitment of juveniles increased rapidly in summer and reached a maximum in August. However, this high density of juveniles did not continue until autumn. The decreased number in September may in part be the result of many individuals being weakened and killed by accumulating temperature stress during the period of high temperature in summer. Winter must be a critical period for population maintenance, because the number of mature females decreased. The adverse conditions for the population as a whole in winter are compensated for by the maintenance of many immature individuals of large size; this results in the production of a large number of eggs in the following spring thus re-establishing the population.

The egg ratio analysis (Fig. 5) revealed that the death rate exceeded the birth rate during April and May even though the birth rate of the overwintering females indicated a high value in spring. This may be the result of many newborn juveniles being killed by exposure to still low temperatures in spring. The high birth rates during summer resulted in greater amphipod densities. Van Dolah (1978) showed that increased death rates during summer in Gammarus palustris living in estuarine salt marshes were due to predator pressure. In the sampling site of Tokyo Harbor, fauna among the blue mussel zone is very scarce; as mobile invertebrates, the crab Hemigrapsus sanguineus, the polychaete Typosyllis adamanteus kurilensis and amphipods were observed. In the quantitative samples, these species - except amphipods - were rarely collected. These species ingest detritus. Therefore, it seems that the presence of these species is not a biological factor influencing the abundance of Hyale 
barbicornis in terms of predator pressure. Fish feeding on $H$. barbicornis would also not be important in regulating amphipod populations, because 'secondary space' produced by the mussel shells themselves (Dayton, 1971) provides a refuge for the amphipods from fishes. Furthermore, we observed that no amphipods move away from the mussel zone during high tide. Thus, the high summer population densities of $H$. barbicornis were maintained due to lack of predator pressure.

The relation between egg number per brood and body length varied seasonally (Fig. 6). In general, the fecundity of amphipods depends on body size. As shown in Fig. 6, large females produced more eggs in spring than small ones in summer. While the body length of females in winter was large comparable to that of females in spring, egg number per brood in winter was low and similar to that of the small females present in summer and autumn. Sheader (1983) stated that the amount of energy expended on reproduction depends on a number of factors including body size, temperature and food availability. In summer, the small mature females cannot produce more eggs than larger ones. Furthermore, with increasing temperature, there is an increase in the proportion of assimilated energy expended on metabolic activities, molt frequency and reproduction. Number of eggs in winter brooding females were very low despite their large body size. It seems that a greater proportion of assimilated energy was directed into growth (not reproduction) due to decreasing feeding activity with decreasing temperature (as Sheader [1978] stated for Corophium insidiosum) or due to shortage in available food in winter. The large size of overwintering mature females led to many eggs in spring. This seems to show that the proportion of assimilated energy was sufficiently directed into both growth and reproduction due to increasing feeding activity with increasing temperature or due to increasing amounts of available food.

Though the concept of generation time is difficult to apply to continuously reproducing populations, size distribution (Fig. 3) and growth experiment (Fig. 7) indicate that there are at least 3 generations in Hyale barbicornis per year: spring-summer (spring generation), summer-autumn (summer generation), and autumn-spring (overwintering generation).

Exposed to extensive differences in seasonal temperature over the year, summer females at high temperatures reveal decreases in mature size, egg number per brood and life time, compared with those of overwintering females at low temperatures. These facts were also recognized when comparing numerous amphipod species living in high versus low latitudes (e.g. Steele and Steele, 1975; Van Dolah and Bird, 1980; Sheader, 1983).

\section{LITERATURE CITED}

Barnard, J. L. (1974). Gammaridean Amphipoda of Australia, Part II. Smithson. Contr. Zool. 139: 1-148

Barnard, J. L. (1979). Littoral Gammaridean Amphipoda from the Gulf of California and the Galapagos Islands. Smithson. Contr. Zool. 271: 1-149

Cooper, W. E. (1965). Dynamics and production of a natural population of a freshwater amphipod, Hyalella azteca. Ecol. Monogr. 35: 377-394

Dayton, P. K. (1971). Competition, disturbance and community organisation: the provision and subsequent utilisation of space in a rocky intertidal community. Ecol. Monogr. 41: $351-389$

Dexter, D. M. (1971). Life history of the sandy-beach amphipod Neohaustorius schmitzi (Crustacea: Haustoriidae). Mar. Biol. 8: 232-237

Hiwatari, T., Kajihara, T. (1981a). Taxonomy of the family Hyalidae (Amphipoda, Crustacea) in Japan. I. Three new species of the genus Hyale. Proc. Japan. Soc. Syst. Zool. 20: $21-34$

Hiwatari, T., Kajihara, T. (1981b). Taxonomy of the family Hyalidae (Amphipoda, Crustacea) in Japan. II. A new species of the genus Hyale. Proc. Japan. Soc. Syst. Zool. 21: $35-40$

Iwasa, M. (1939). Japanese Talitridae. J. Fac. Sci. Hokkaido Imp. Univ. (Zool.) 6: 255-296

Joseph, M. M. (1972). Tidal rhythm in the feeding of the intertidal amphipod Hyale hawaiensis (Dana). Proc. Indian Acad. Sci. 388: 456-461

Moore, P. G. (1977), Organization in simple communities: observations on the natural history of Hyale nilssoni (Amphipoda) in high littoral seaweeds. In: Keegan, B. F., O'Ceidigh, P., Boaden, P. J. S. (ed.) Biology of benthic organisms. Pergamon Press, Oxford, p. 443-451

Sheader, M. (1978). Distribution and reproductive biology of Corophium insidiosum (Amphipoda) on the north-east coast of England. J. mar. biol. Ass. U. K. 58: 585-596

Sheader, M. (1983). The reproductive biology and ecology of Gammarus duebeni (Crustacea: Amphipoda) in southern England. J. mar. biol. Ass. U. K. 63: 517-540

Steele, D. H., Steele, V. J. (1975). The biology of Gammarus (Crustacea, Amphipoda) in the northwestern Atlantic. XI. Comparison and discussion. Can. J. Zool. 53: 1116-1126

Van Dolah, R. F. (1978). Factors regulating the distribution and population dynamics of the amphipod Gammarus palustris in an intertidal salt marsh community. Ecol. Monogr. 48: 191-217

Van Dolah, R. F., Bird, E. (1980). A comparison of reproductive patterns in epifaunal and infaunal gammaridean amphipods. Estuar. coast. mar. Sci. 11: 593-604

Van Dolah, R. F., Shapiro, L. E., Rees, C. P. (1975). Analysis of an intertidal population of the amphipod Gammarus palustris using a modified version of the egg-ratio method. Mar. Biol. 33: 323-330 